\title{
Endosymbiosis in Trypanosomatids as a Model to Study Cell Evolution
}

\author{
Maria Cristina M. Motta*
}

\author{
Laboratório de Ultraestrutura Celular Hertha Meyer, Instituto de Biofísica Carlos Chagas Filho, Universidade Federal \\ do Rio de Janeiro, Av. Carlos Chagas Filho, 373, bloco G subsolo, Cidade Universitária, Ilha do Fundão, Rio de \\ Janeiro, 21941-902, Brazil
}

\begin{abstract}
Some trypanosomatids harbor a symbiotic bacterium, which maintains a close association with the host, constituting an excellent model to study organelle origin and cellular evolution. Molecular data show that all endosymbiontharboring trypanosomatids are grouped together in a single phylogenetic branch. According to rRNA sequences, symbionts of different species are similar, being classified in the $B$ division of Proteobacteria, thus suggesting that a single evolutionary event gave rise to the symbiosis in the Trypanosomatidae family. The bacterium is enclosed by two unit membranes and presents a reduced peptidoglycan layer, which is essential for cell division and morphological maintenance. Regarding the protein composition, the number of intramembrane particles in the endosymbiont envelope is similar to that described for Gram-negative bacteria. Lipid analyses of purified endosymbionts show absence of sterols and indicate phosphatidylcholine as a major component of the envelope, as described in other intracellular bacteria. The presence of the endosymbiont is associated with distinct ultrastructural and physico-chemical alterations in the trypanosomatid and influences the protozoan interaction with the insect host and mammalian cells. Symbiont-containing trypanosomatids are able to infect and to replicate inside fibroblasts and macrophages, whose microbicidal activity was deactivated by HIV-1 infection. The symbiosis in trypanosomatids is characterized by intensive metabolic exchanges; the bacterium expresses enzymes and metabolic precursors that complete essential biosynthetic pathways of the protozoan. Conversely, the symbiont is capable of obtaining part of the required energetic molecules from the host glycosomes. Taken together data suggest that endosymbiosis in trypanosomatids represents an interesting model to study cell evolution.
\end{abstract}

Keywords: Trypanosomatidae, Proteobacteria, Endosymbiont, Organelle origin, Cellular evolution.

\section{INTRODUCTION}

There are numerous hypotheses to explain the origin of eukaryotes, all of them consider a co-evolution by endosymbiosis between microorganisms, as archea and bacteria [1]. Trypanosomatids are valuable models to understand, at least in part, the origin of organelles in the eukaryotic cell, as well as the colonization and survival of symbionts and parasites within host cells. This group of flagellated protozoa is exclusively composed by parasites that live in association with plants and animals; some are agents of human illnesses, as Chagas disease and leishmaniasis, but the majority presents a single invertebrate host during all its life cycle, thus named monoxenous protozoa. Five species of insect trypanosomatids harbor an obligate intracellular bacterium. A mutualistic relationship maintains both organisms together, since the endosymbiont is unable to survive and replicate once isolated from the host, whereas aposymbiotic trypanosomatids are incapable of colonizing insects [2,3].

The endosymbiont of trypanosomatids was first described as diplosomes in Blastocrithidia culicis, a species isolated from the hemipteron Triatoma infestans, each flagellate usually harboring a single diplosome [4]. Fifty years later, a similar structure was described in Crithidia oncopelti

*Address correspondence to this author at the Laboratório de Ultraestrutura Celular Hertha Meyer, Instituto de Biofísica Carlos Chagas Filho, Universidade Federal do Rio de Janeiro, Av. Carlos Chagas Filho, 373, bloco G subsolo, Cidade Universitária, Ilha do Fundão, Rio de Janeiro, 21941- 902, Brazil; Tel/Fax: 55-21-2260-2364; E-mail: motta@biof.ufrj.br as bipolar bodies, a basophilic rod-like organelle, capable of self-reproduction and largely composed by ribonucleoproteins [5]. Thereupon, it was suggested that $C$. oncopelti contained a symbiotic bacterium, which provided the host trypanosomatid with biosynthetic capabilities [6]. Bipolar bodies also were reported on Crithidia deanei, a trypanosomatid isolated from the hemipteron Zelus leucogrammus. Such protozoan presented limited requirements for growth, reinforcing the idea that the symbiont supplied the host with essential nutrients [7]. According to ultrastructural analysis of antibiotic treated trypanosomatids, it was concluded that diplosomes and bipolar bodies corresponded to the same structure, thus called endosymbionts [8]. Later on, two new species of trypanosomatids containing endosymbiont were isolated from the fly Ornidia obesa: Crithidia desouzai and Herpetomonas roitmani $[9,10]$ (Table 1). Ultrastructural and imunocytochemical data revealed that $C$. desouzai also contains virus-like particles (VLPs) in the cytoplasm. Such particles, which present a hexagonal array, are usually observed close to the protozoan nucleus and are composed by RNA $[11,12]$.

Once treated with penicillin or chloramphenicol the host trypanosomatid looses the bacterium, thus generating a cured or aposymbiotic strain $[5,6,13,14]$. Furthermore, it is possible to obtain a pure fraction of endosymbionts after cell fractioning of the host cell using sonication or immunolysis, followed by differential centrifugation in sucrose or Percoll gradients [5, 15-17]. The comparative study between symbiont-bearing and aposymbiotic strains, as well as biochemical 
Table 1. Endosymbiont-Bearing Trypanosomatids Isolated from Insects

\begin{tabular}{|c|c|c|}
\hline Trypanosomatid Species & Insect Host & References \\
\hline \hline Blastocrithidia culicis & Triatoma infestans & {$[4]$} \\
\hline Crithidia deanei & Zelus leucogrammus & {$[7]$} \\
\hline Crithidia desouzai & Ornidia obesa & {$[5]$} \\
\hline Crithidia oncopelti & Oncopeltus fasciatus & {$[9,10]$} \\
\hline Herpetomonas roitmani & Ornidia obesa & \\
\hline
\end{tabular}

assays with isolated bacteria have opened up new possibilities to study the endosymbiosis in trypanosomatids and to better understand the appearance of bacterial origin organelles in eukaryotic cells.

\section{THE ENDOSYMBIOSIS IN TRYPANOSOMATIDS REPRESENTS A SINGLE EVENT IN EVOLUTION}

Data obtained by isoenzyme eletrophoresis and also after sequencing the $16 \mathrm{~S}$ ribosomal RNA gene revealed that endosymbiont-harboring trypanosomatids are grouped together in a monophyletic cluster, when compared to other protozoa of the same genus. Thus, Blastocrithidia, Crithidia and Herpetomonas species containing the symbiotic bacterium compose an independent phylogenetic branch in relation to other protozoa of the same genera [10, 18-21] (Fig. 1). For this reason, a new taxonomic classification was proposed to cho-

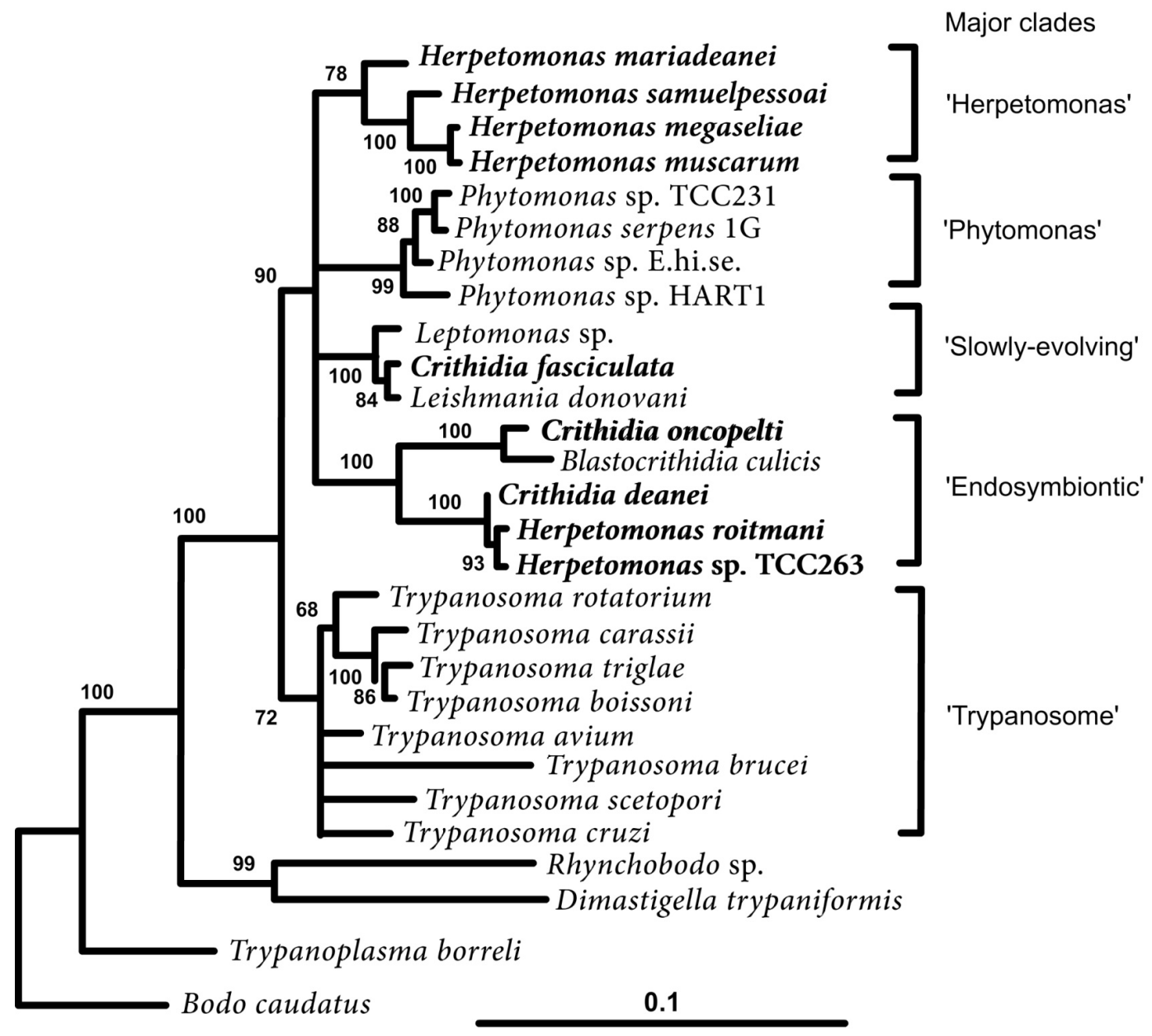

Fig. (1). Majority consensus likelihood SSU rRNA tree of Trypanosomatidae. Search options with fastDNAm program included empirical base frequencies, randomized sequence addition order and global arrangements. Ln-likelihood value of the maximum likelihood tree is 9092.81296. Scale bar corresponding to 0.1 substitutions per site is shown under tree. Members of the polyphyletic genera Herpetomonas and Crithidia are shown in boldface. Reprinted from J Euk Microbiol 1998, 45: 293-297, Hollar et al. "Monophyly of endosymbiont containing trypanosomatids: phylogeny versus taxonomy", with permission from Wiley-Blackwell, Oxford, UK. 
anomastigote-shaped trypanosomatids that harbor the symbiont, with the inclusion of the genus Angomonas [22, 23].

Regarding the origin of the endosymbiont in trypanosomatid protozoa, molecular analysis of small-subunit ribosomal DNA showed that B. culicis and Crithidia symbionts share high identity, suggesting that they descend from a commom ancestor, a $\beta$-Proteobacteria of the genus Bordetella $[19,24]$ (Fig. 2). The first study with the endosymbiont DNA showed a $\mathrm{G}+\mathrm{C}$ content of $32 \%$, which is similar to that described in most bacteria [25]. Taken together data suggest that the endosymbiosis in trypanosomatids represents a unique event, which involved the acquisition of a Bordetella Proteobacterium by an ancestral host, followed by the coevolution of both partners into different species.

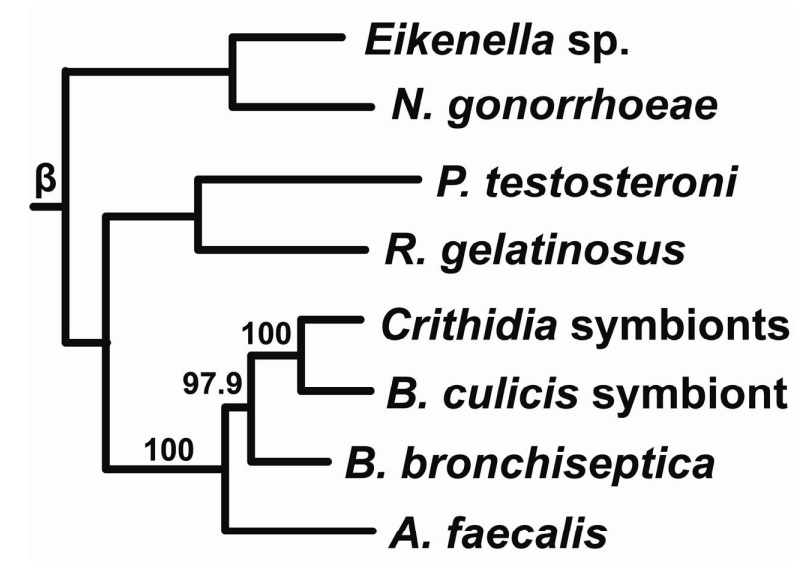

Fig. (2). Parsimony phylogenetic tree of the $16 \mathrm{~S}$ rDNA sequences from symbionts and $\beta$-division purple bacteria. Confidence levels determined by bootstrap analysis for the endosymbionts and close relatives are shown above the branches. Reprinted from Proc Natl Acad Sci USA 1994; 91: 8437-8441, Du et al. "Monophyletic origin of L-division proteobacterial endosymbionts and their coevolution with insect trypanosomatid protozoa Blastocrithidia culicis and Crithidia spp.", with permission from Copyright (1994) National Academy of Sciences, USA.

\section{ULTRASTRUCTURAL AND BIOCHEMICAL CHAR- ACTERISTICS OF THE SYMBIOTIC BACTERIUM}

The endosymbiont in trypanosomatids is enclosed by two unit membranes, the inner one corresponds to the plasma membrane and is in contact with the bacterial matrix, while the outer membrane faces the host protozoan cytoplasm. The origin of the outer membrane is controversial; it could represent part of the cell envelope of a Gram-negative bacterium, but conversely it could be derived from the host protozoan $[26,27]$. Data obtained by the freeze-fracture technique showed that the number and pattern of distribution of intramembranous particles (IMPs) on both faces of the symbiont outer membrane are significantly different from those of the host protozoan plasma membrane. However, such distribution of membrane particles is similar to that observed in Gram-negative bacteria [28, 29].

The intermembrane space in Gram-negative bacteria is designated as periplasmic space and is usually occupied by a peptigoglycan layer, also referred to as cell wall. Such struc- ture is not observed in the symbiont of trypanosomatids, which differently from bacteria but similar to most mitochondrion lacks the septum and also the $\mathrm{Z}$ ring, structures which play essential roles in bacterial division [28-30]. However, when endosymbiont-harboring trypanosomatids are grown in medium containing $\beta$-lactam antibiotics, which blocks the peptidoglycan layer synthesis, the bacterium presents morphological alterations and is incapable of division, culminating in its cell lysis. These data indicate that a reduced cell wall may exist in the endosymbiont, playing important physiological roles as in shape maintenance and in bacterial division [17].

According to ultrastructural data, the symbiont matrix presents a granular electron-dense area containing ribosomes and a filamentous electron-lucid region with the genetic material $[12,28,29]$. The bacterium matrix also contains structural proteins, enzymes and metabolic intermediates that complement essential biosynthetic pathways of the host protozoan, as will be discussed later on.

Biochemical studies showed that similar to most prokaryotes, the endosymbiont envelope does not contain any type of sterol. Regarding the phospholipid composition, cardiolipin is the major constituent of symbiont membranes, followed by similar amounts of phosphatydilcholine (PC) and phosphatidylethanolamine and a minor quantity of phosphatidylinositol [31]. It is important to point out that PC, the major structural component in most eukaryotic cell membranes, is usually absent in prokaryotes, except in species closely associated with plant or animal hosts [32]. In such cases, PC is essential to maintain the symbiotic and pathogenic interactions, as well as the prokaryote virulence [33, 34].

The endosymbiont phospholipid content is significantly altered when the host protozoan is growth in the presence of lipid biosynthesis inhibitors, such as 22,26-azasterol, resulting in a decrease of the PC level in the bacterium [31]. When the host trypanasomatid is cultivated in medium containing ${ }^{32} \mathrm{Pi}$ and then is submitted to cell fractioning, $\mathrm{PC}$ was the main radiolabeled phospholipid detected in the symbiont fraction. Interestingly, once isolated from the host cell and incubated in culture medium containing ${ }^{32} \mathrm{Pi}$, the endosymbiont is capable of synthesizing phospholipids independently from the protozoan, however the PC content is highly reduced [35]. Taken together, we suggest that the endosymbiont takes, at least in part, PC or PC precursors from the host cell, reinforcing the idea that this phospholipid contributes to the establishment of the symbiosis in trypanosomatids. Isolated symbionts are also able to synthesize proteins [36], indicating that although it maintains a close association with the host cell, it is still autonomous to produce essential molecules. Probably, the endosymbiont in trypanosomatids represents an intermediate evolutionary step between bacteria and organelles.

THE PRESENCE OF THE ENDOSYMBIONT IS ASSOCIATED TO ULTRASTRUCTURAL AND BIOCHEMICAL ALTERATIONS IN THE HOST TRYPANOSOMATID

As with other protozoa from the Trypanosomatidae family, symbiont-containing species present: a single flagellum that emerges from a flagellar pocket, a unique and branched 


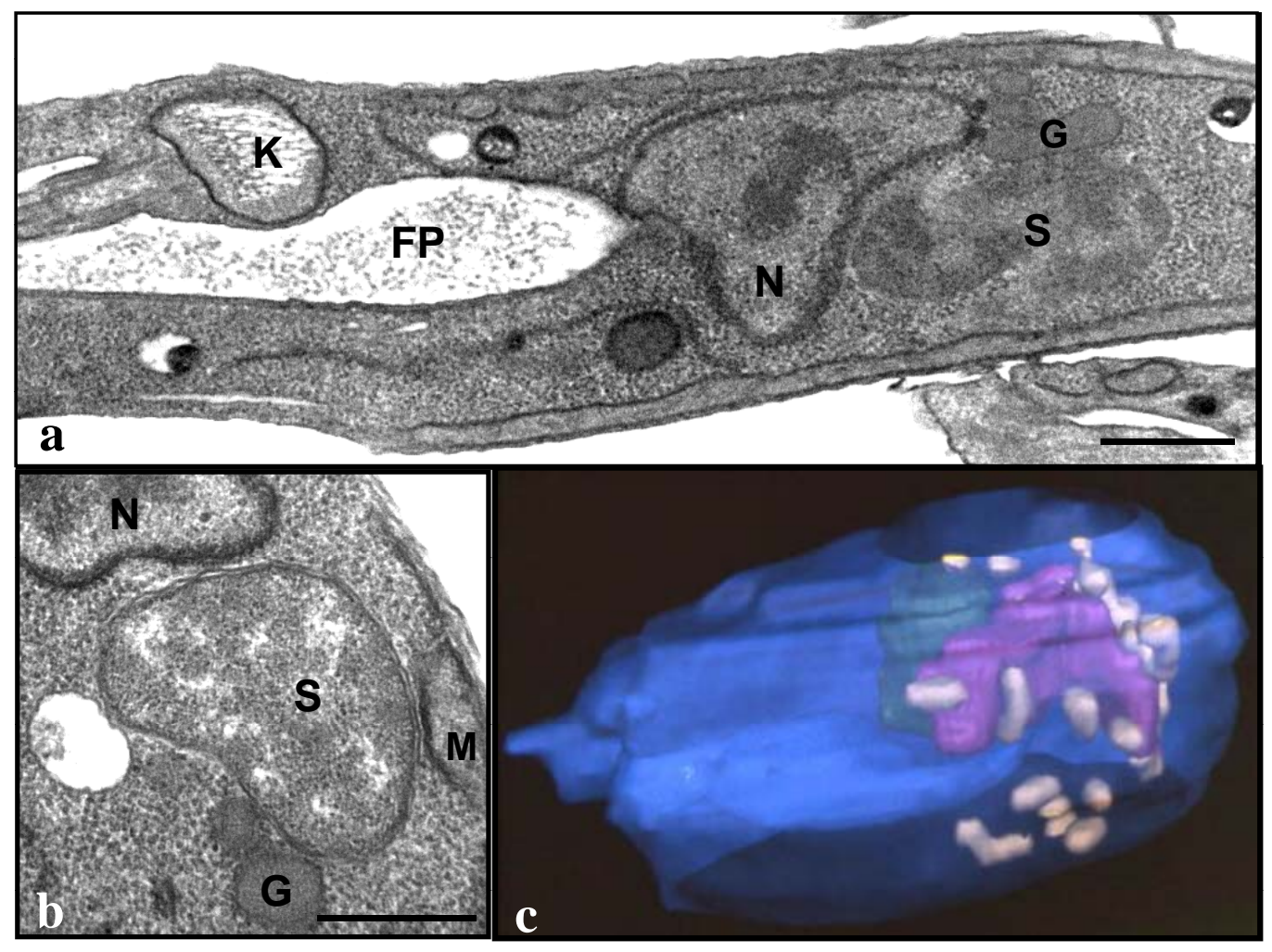

Fig. (3). (a-b) Ultrastructure of Crithidia deanei obtained by transmission electron microscopy, showing the kinetoplast (K), flagellar pocket $(\mathrm{FP})$, glycosome $(\mathrm{G})$, portions of the mitochondrion (M) located at the periphery of the protozoan, nucleus (N) and symbiont (S). Note that the symbiont is enclosed by two unit membranes (b) - Bars: $1 \mu \mathrm{m}$, micrographs by Cristina Motta. Three-dimensional reconstruction of 12 planes of $C$. deanei, note the close association between the dividing endosymbiont (magenta) with the nucleus (green) and glycosomes (yellow), as also observed in figures a and b. Cell membranes are in blue color. Three-dimensional reconstruction by Marcia Attias, Cristina Motta and National Center for microscopy and image research at San Diego, CA/USA.

mitochondrion whose DNA is contained in the kinetoplast, glycosomes a special type of peroxisome that contain the glycolytic pathway, and a cytoskeleton formed by subpellicular microtubules organized in a cage array [37]. The three-dimensional reconstruction of symbiont-harboring trypanosomatids indicates that the bacterium is in close association with the host cell nucleus and is usually surrounded by glycosomes [38, 39] (Fig. 3). The synchrony in cellular division is another remarkable feature of this symbiotic relationship: the endosymbiont divides in coordination with other cellular structures, thus each daughter cell carries just a single bacterium [2].

The presence of the symbiotic bacterium is related to ultrastructural modifications on the host trypanosomatid. In such case, the subpellicular microtubules are absent in sites where the mitochondrial branches are juxtaposed to the plasma membrane and the kinetoplast presents a typical round shape with a more relaxed arrangement of the kDNA fibers $[40,41]$. Furthermore, the paraflagellar rod, which is involved in adhesion and cell motility, is greatly reduced in symbiont-harboring trypanosomatids [42-44] (Fig. 4). Surprisingly, such protozoa are able not only to attach to the insect midgut [3], but also to disrupt the tight junctions of epithelial cells to reach the haemocel [45]. These results suggest that the paraflagellar rod is not essential to cellular motility and insect colonization, at least in symbiont- containing trypanosomatids. It is worth mentioning that removal of the symbiotic bacterium by antibiotic treatment did not reverse the protozoan characteristics [40].

The symbiotic association also promotes physicochemical alterations in the host trypanosomatids. Thus, the presence of the bacterium greatly influences the polysaccharide and glycoprotein composition, as well as the general carbohydrate exposition on the protozoan plasma membrane [46-50]. Measurements of cellular electrophoretic mobility revealed that the aposymbiotic strain of $C$. deanei presents a high negative surface charge, when compared to symbiontharboring cells [51]. Furthermore, the absence of the symbiotic bacterium enhances de differentiation process in Herpetomonas roitmani. Thus, the ophistomastigote form predominates in cured cells as compared with the symbiontharboring strain, in aging cell cultures [49].

\section{THE INTERACTION OF TRYPANOSOMATIDS WITH THE INSECT HOST AND MAMMALIAN CELLS IS INFLUENCED BY THE SYMBIOTIC BAC- TERIUM}

As previously assumed, monoxenous trypanosomatids parasite invertebrates, specially insects belonging to Diptera and Hemiptera orders [52]. The colonization of insects by trypanosomatids is directly dependent on the protozoa interaction with host cells and organs. The complete life cycle of 


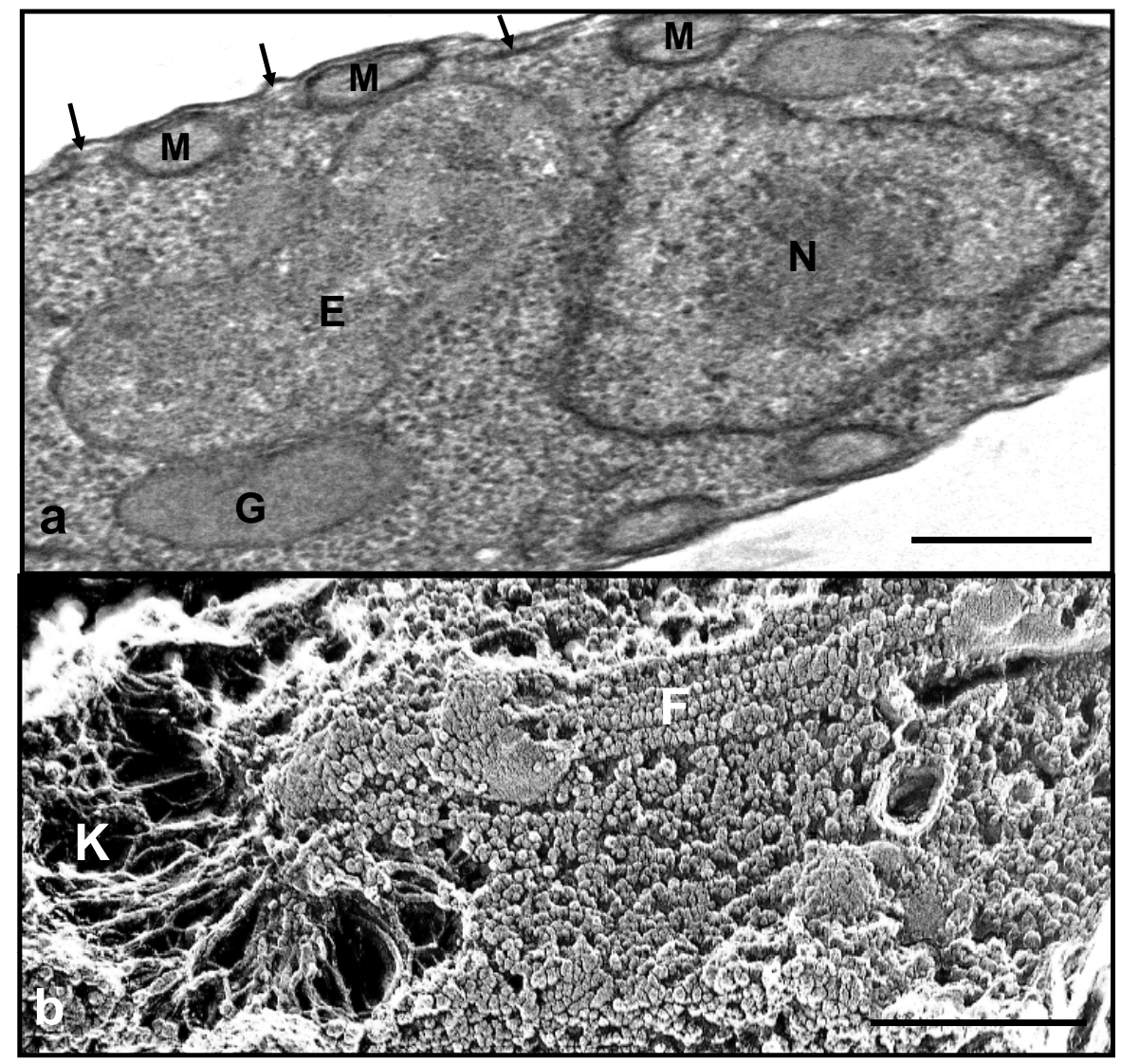

Fig. (4). Ultrastructure of $C$. deanei obtained by transmission electron microscopy (a) and by the freeze fracture followed by the deepetching technique (b). Note that in this endosymbiont-bearing trypanosomatid the microtubules (arrows) are absent in sites where the mitochondrial branches (M) are juxtaposed to the plasma membrane. Other ultrastructural alterations associated to these cells are the presence of a round kinetoplast $(\mathrm{K})$ presenting a looser arrangement of the kDNA fibers and a typical flagellum (F) containing a reduced paraflagellar rod (b). Bars: $1 \mu \mathrm{m}$. Micrographs by Cristina Motta. E- endosymbiont, $\mathrm{G}$ - glycosome, $\mathrm{N}$ - nucleus.

monoxenic trypanosomatids is not well established, but the insect midgut has been described as the preferential colonization site. However, such protozoa are also found within Malphigian tubules, as well as in the hemolymph and the haemocel $[45,52,53]$.

Studies of cellular interaction showed that endosymbiontbearing cells interact better with insect cell lines and explanted guts, when compared with their aposymbiotic counterpart strains. Such data revealed that Blastocrithidia culicis is the species which best associates with Diptera, in special with Aedes mosquitoes, thus constituting an attractive model to study the monoxenous protozoan-insect interaction. Furthermore, cured cells are unable to colonize insects, revealing that the symbiont is essential for the trypanosomatid existence in nature, which characterizes an obligate and mutualist association between both partners [3] (Fig. 5).

Several factors influence the interaction of endosymbiont-containing species with the insect midgut. Proteolytic enzymes play essential roles in host-parasite relationship, which includes cell attachment, survival and pathogenesis [54]. The metallopeptidase gp63, a major glycoprotein found in the leishmanial cell surface is also present in $C$. deanei. This protein is anchored to the plasma membrane via the glycosylphosphatidylinositol (GPI) and mediates the adhesive process of the protozoan to Aedes aegypti explanted guts, as demonstrated using anti-gp63 antibodies and phospholipase C (PLC). The higher expression of gp63-like molecules on the surface of symbiont-bearing trypanosomatids, when compared to the aposymbiotic cells, may be correlated with a more efficient interaction of the wild strain with insect guts [55].

Glycoconjugates are essential for a specific association between protozoa and host cells, which can be mediated by the interaction of carbohydrate-binding proteins, also known as lectin-like molecules [56-58]. Symbiont-containing and cured strains present different patterns of glycoconjugates, which influences the protozoa interaction with explanted guts from A. aegypti. The treatment of both strains of $B . \mathrm{Cu}$ licis and $C$. deanei with sialidase, reduces in at least $90 \%$, the interaction between such trypanosomatids and explanted guts. Furthermore, the interaction of symbiont-harboring cells with insect guts was inhibited in the presence of mucin, fetuin, sialyllactose and methylmannosidase, thus indicating that sialomolecules and mannose-rich glycoconjugates are involved in monoxenous-host invertebrate interaction [50].

While considered nonpathogenic, infections caused by monoxenic trypanosomatids have been described in different vertebrate hosts $[59,60]$. The ability of symbiont-harboring trypanosomatids to interact, to invade and to multiply inside host cells is related to the protozoan cell surface composi- 


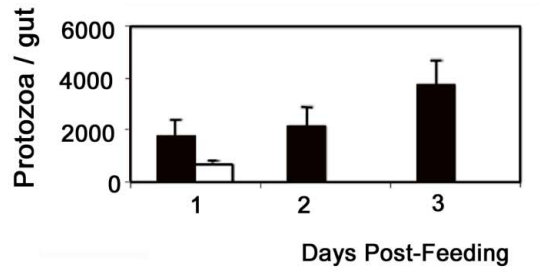

a

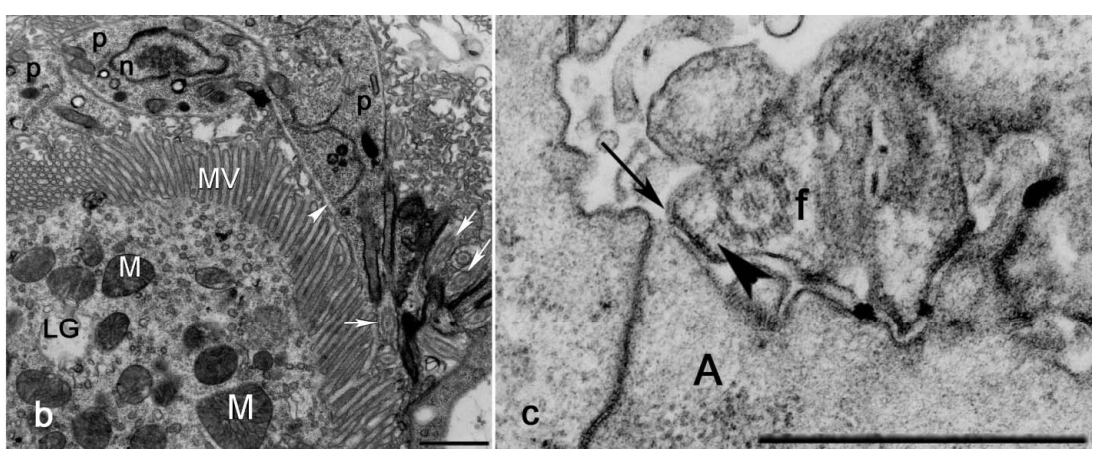

Fig. (5). (a) Outcome of infections in A. aegypti after artificial feeding on cultures of B. culicis endosymbiont-harboring (solid bar) and cured (open bar) strains. Histograms represent the number of protozoa in mosquito guts (mean \pm SEM) of two experiments in which 7-10 insects were examined per time-point. (b-c) Transmission electron microscopy of the interaction between B. culicis and explanted guts of Lutzomyia longipalpis (b) and Aedes albopictus (c). (b) Protozoa (p) interact with gut microvilli (MV) via cell body (arrowhead) and via flagella, which can be seen inserted between microvilli (arrows). (c) Longitudinal section showing the attachment of B. culicis flagellum to A. albopictus epithelium gut (AG). Note the presence of dense hemidesmosome plaque along the flagellar membrane attached to the epithelium (arrow). The flagellum (f) is greatly expanded and presents filaments connecting the axoneme to the attached flagellar membrane (arrowhead). Mitochondrion (M), nucleus (n). Bars: $1 \mu \mathrm{m}$. Reprinted from Int J Parasitol 2003, 33: 1019-1026, Fampa et al. "Interaction of insect trypanosomatids with mosquitoes, sand fly and the respective insect cell lines", with permission from Elsevier.

tion, which is influenced by the presence of the bacterium, as previously mentioned. It has been reported that once inside the host cell, the symbiont-harboring strain of $C$. deanei is more resistant to the macrophage killing mechanisms [61], also promoting increased cell death in infected fibroblasts [62], when compared to the aposymbiotic strain. In vitro assays demonstrated that symbiont-harboring trypanosomatids, but not the symbiont-free trypanosomatids are able to infect and to survive for $48 \mathrm{~h}$ inside dermal mouse fibroblasts [63]. Since these cells are numerous in the skin, they can represent a potencial target for early infection and spreading [64]. Recently, it was shown that the symbiont-harboring strain of $C$. deanei presents a higher interaction rate with mammalian fibroblasts at the very beginning of the interaction process (1-2h). However, as the assay proceeds (24$96 \mathrm{~h}$ ), the association index is similar in both strains, indicating that the protozoan ability to survive and replicate inside the host cell is independent of the presence of the endosymbiont. Such interaction is mediated by leishmanolysin, a surface metallopeptidase which promotes association between Leishmania and macrophages, which is highly expressed in symbiont-harboring $C$. deanei [62].

Interestingly, monoxenous trypanosomatids were isolated from HIV-positive patients, promoting visceral or cutaneous leishmaniasis-like lesions $[65,66]$. Recently, it was demonstrated that $B$. culicis not only survive, but also replicates, in human macrophages whose microbicidal activity was deactivated by HIV-1 infection [67]. Taking together these data indicate that monoxenous trypanosomatids are opportunistic pathogens in immunocompromised patients [68].

\section{METABOLIC EXCHANGES BETWEEN THE ENDO- SYMBIONT AND ITS HOST TRYPANOSOMATID}

Mutualism is a symbiotic relationship between different organisms in which both partners gain benefits from the association. This concept usually assumes that individuals rely on one another for nutrients and other life functions. In en- dosymbiont-harboring trypanosomatids intense metabolic changes occur between the host cell and the bacterium: the prokaryote complement important biosynthetic pathways of the protozoa and in exchange receives growth factors, suitable physical conditions and energy supply.

Lwoff [69] was the first to report that Crithidia oncopelti presented low nutritional requirements and that differently from other trypanosomatids, this symbiont-containing species was able to grow in culture medium without any source of hemin. Later on, it was established that the bacteriumharboring species could grown in chemically defined medium containing few vitamins and aminoacids, as methionine and tyrosine, and usually with no source of hemin or purin. Such culture medium can not support the growth of naturally symbiont-free species or even the cultivation of aposymbiotic strains obtained after antibiotic treatment, suggesting that the endosymbiont benefits the growth of their hosts by supplying essential factors [7, 9, 49, 70-73]. According to this idea, endosymbiont-harboring trypanosomatids show a reduced secretion of extracellular proteinases, which presents a proteolytic digestive role, when compared to cured strains [72].

A special nutritional feature of flagellates is their requirements for heme compounds, usually supplied as hemin, hematin or hemoglobin. Trypanosomatid are able to catalyze the insertion of iron into protoporphyrin IX, indicating that it contains ferrochelatase, the terminal enzyme in the heme biosynthesis [73]. However, only symbiont-bearing protozoa dispense hemin for growth and this is related to the ability of the bacterium to complement the host pathway for heme biosynthesis with enzymes and metabolic precursors. It was demonstrated that the symbiotic bacterium contains uroporphyrinogen I synthase, thus enhancing the very limited heme biosynthethetic capability of the host cell [73], as well as enzymes involved in porphyrin synthesis [74]. Taken together, data suggest that both partners, the symbiont and the 
host trypanosomatid, do complementary and essential contributions to complete the heme biosynthetic pathway.

Regarding the metabolism of aminoacids, differently from other trypanosomatids, symbiont-harboring protozoa are capable of isoleucine synthesis, since the first enzyme of this biosynthetic pathway is present in the symbiotic bacterium. Furthermore, species containing the endosymbiont do not require the metabolically related aminoacids, valine and leucine [16]. Species bearing the symbiont are also autonomous for lysine production, due to the presence of diaminopimelic decarboxylase, the last enzyme of this pathway, in the bacterium $[6,75]$.

Studies of the urea cycle in trypanosomatids have shown that symbiont-free species of Crithidia need exogenous arginine or citrulline in culture medium, but not ornithine, which does not substitute for either aminoacids. In such protozoa the enzyme arginase converts arginine into ornithine and the citrulline can be splitted into ornithine, ammonia and carbon dioxide by citrulline hydrolase. Differently, in symbiont-harboring species of Crithidia the urea cycle is complete and such aminoacids are not required for cellular growth. This is related to the presence of enzymes in the symbiotic bacterium, as acetylornithinase, which converts acetylornithine in ornithine, and ornithine carbamoyltransferase (OCT), which transforms ornithine in citrulline, as demonstrated by biochemical and cytochemical assays [7678] (Fig. 6).

In trypanosomatids, the production of ornithine in urea cycle can lead to the simultaneous production of carbamoyl phosphate, used in the synthesis of pyrimidines, as well as to the synthesis of proline and putrescine, a type of polyamine [79-81]. Usually trypanosomatids do not require proline, a relevant metabolic factor, in the culture medium [82, 83]. In
C. deanei, a single type of proline transporter is present in symbiont-harboring or symbiont-free strains, whose activity is up-regulated by the presence of the symbiotic bacterium [84]. The ornithine production is directly associated to the polyamine biosynthesis, which is catalyzed by the enzyme ornithine decarboxylase (ODC), which converts ornithine into putrescine $[85,86]$. Endosymbiont-harboring trypanosomatids present higher ODC activity when compared to the aposymbiotic cells and this is related to the production of protein factors by the symbiotic bacterium, thus increasing the host polyamine metabolism [87]. Since polyamines are essential for cell growth and differentiation, the increased production of these polycations in symbiont-harboring trypanosomatids, explains in part why these protozoa grow faster in culture medium, when compared to symbiont-free trypanosomatids [26, 49].

There are scanty data indicating that the symbiont receives metabolites and nutritional factors from the host trypanosomatid. However, its inability to survive once isolated from the protozoan, strongly suggest that the bacterium obtains essential nutrients and metabolic precursors produced by the host cell. As previously mentioned the bacterium seems to obtain part of the phosphatidylcoline, a component of its envelope, from the host cell [35]. Other studies suggest that the symbiotic bacterium may obtain part of the energetic molecules required for its metabolism from host protozoan glycosomes, which are involved in ATP biosynthesis by the glycolytic pathway. This idea is reinforced by the low enzymatic activity of respiratory chain enzymes and by the presence of an ecto-ATPase in the symbiont surface, as also observed for other obligate intracellular bacteria. Taken together the data suggest that the endosymbiont in trypanosomatids hydrolyze ATP obtained from the host glycosomes to generate a proton motive force that would maintain the

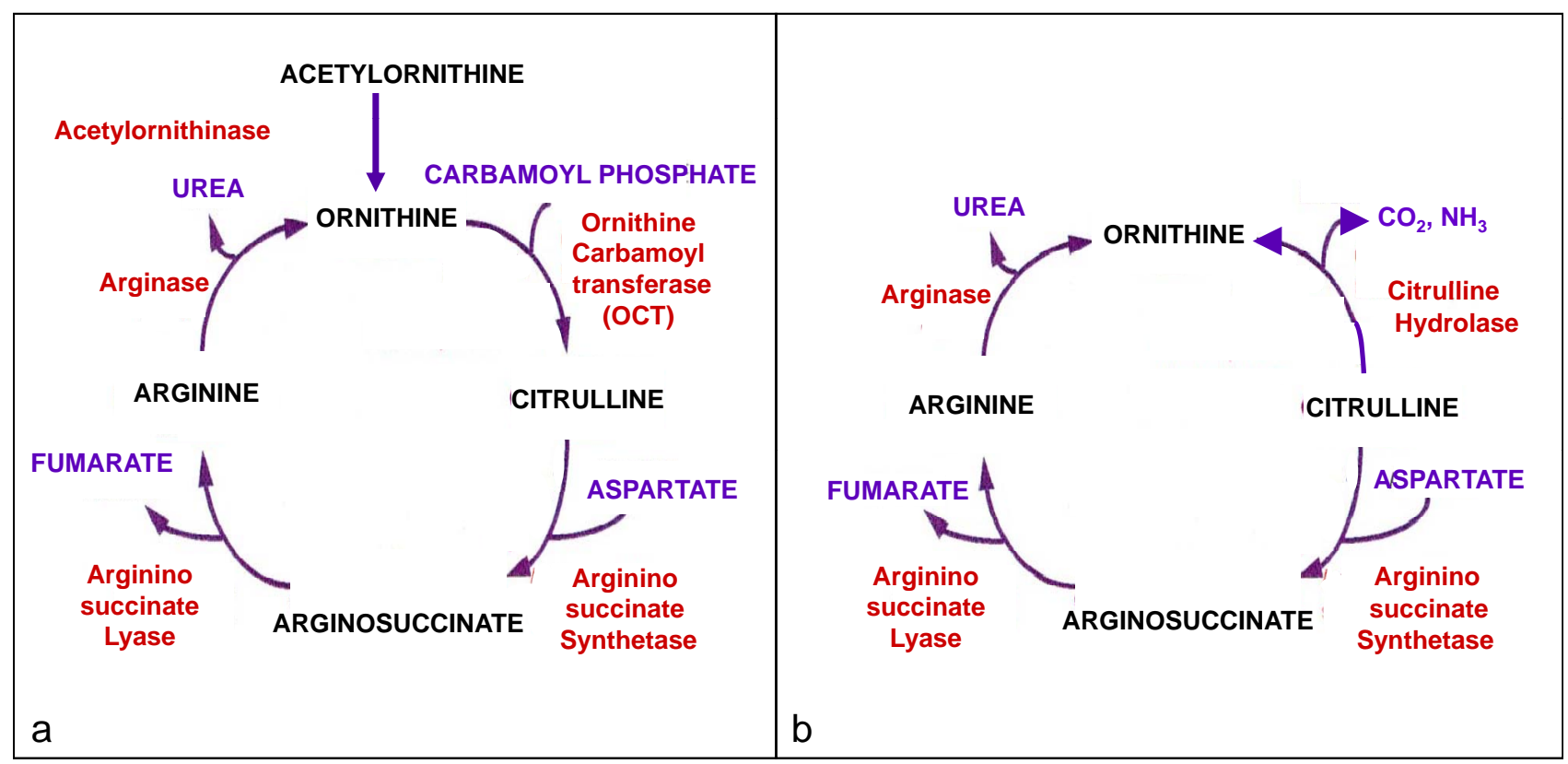

Fig. (6). Urea cycle in endosymbiont-containing (a) and endosymbiont-free (b) Crithidia species. Note that the enzyme ornithine carbamoyltransferase is only present in endosymbiont-bearing strains, closing the urea cycle in these protozoa. Conversely, the citrulline hydrolase is only found in endosymbiont-free species that need exogenous arginine or citrulline in culture medium, but not ornithine, which does not substitute for either aminoacids. 
transport of compounds from the protozoan cytoplasm [38]. The investigation of nutritional aspects in symbiontharboring trypanosomatids not only elucidates the bacterium-protozoan metabolic relationship, but also brings some light on regulation and biogenesis of organelles in the eukaryotic cell.

\section{ACKNOWLEDGEMENTS}

I would like to thank Dr. Wanderley de Souza for the critical revision of the manuscript and Allan de Azevedo Martins for assistance with the figures.

\section{REFERENCES}

[1] Poole AM, Penny D. Evaluating hypotheses for the origin of eukaryotes. Bioessays 2007; 29: 74-84.

[2] De Souza W, Motta MCM. Endosymbiosis in Trypanosomatids. FEMS Microbiol Lett 1999; 173: 1-8.

[3] Fampa P, Corrêa-da-Silva MS, Lima DC, et al. Interaction of insect trypanosomatids with mosquitoes, sand fly and respective insect cell lines. Int J Parasitol 2003; 33: 1019-26.

[4] Novey FG, McNeal WJ, Torrey HN. The trypanosomes of mosquitoes and other insects. J Infect Dis 1907; 4: 223-76.

[5] Newton BA, Horne RW. Intracelular structuresin Strigomonas oncopelti: 1 cytoplasmatic structures ribonucleoprotein. Exp Cell Res 1957; 13: 563-74.

[6] Gill JW, Vogel HJ. Lysine synthesis and phylogeny: biochemical evidence for a bacterial-type endosymbiote in the protozoon Herptomonas (Strigomonas) oncopelti. Biochem Biophys Acta 1962; 56: $200-1$.

[7] Mundim MH, Roitman I, Hermans MA, Kitajima EW. Simple nutrition of Crithidia deanei, a reduviid trypanosomatid with an endosymbiont. J Protozool 1974; 21: 518-1.

[8] Chang KP. Reduced growth of Blastocrithidia culicis and Crithidia oncopelti freed of intracellular symbiotes by chloramphenicol. J Protozool 1975; 22: 271-6.

[9] Fiorini JE, Faria e Silva PM, Soares MJ, Brazil RP. Três novas espécies de tripanosomatídeos isolados em Alfenas, Minas Gerais, Brasil. Mem Inst Oswaldo Cruz 1989; 84: 69-74.

[10] Faria e Silva PM, Sole-Cava AM, Soares MJ, et al. Herptomonas roitmani (Fiorini et al., 1989) n. Comb.: a trypanosomatid with a bacterium-like endosymbiont in the cytoplasm. J Protozool 1991; 38: 489-94.

[11] Soares MJ, Motta MCM, De Souza W. Bacterium-like endosymbiont and virus-like particles in the trypanosomatid Crithidia desouzai. Microbios Lett 1989; 41: 137-41.

[12] Motta MCM, De Souza W, Thiry M. Immunocytochemical detection of DNA and RNA in endosymbiont-bearing trypanosomatids. FEMS Microbiol Lett 2003; 221: 17-23.

[13] Bruesk WA. The diplosome of Blastocrithidia culicis. (Novy, McNeal and Torry, 1907). Ph.D. dissertion, University of Minnesota, Minneapolis, MN 1967; pp. 73-401.

[14] Mundim MH, Roitman I. Extra-nutritional requirements of artificially aposymbiotic Crithidia deanei. J Protozool 1977; 24: 329-31.

[15] Tuan RS, Chang KP. Isolation of intracellular symbionts by immune lysis of £agellate protozoa and characterization of their DNA. J Cell Biol 1975; 65: 309-23.

[16] Alfieri SC, Camargo EP. Trypanosomatidae: isoleucine requirement and threonine deaminase in species with and without endosymbionts. Exp Parasitol 1982; 53: 371-80.

[17] Motta MCM, Monteiro-Leal LH, De Souza W, Almeida DF, Ferreira LCS. Detection of penicillin-binding proteins in endosymbionts of the trypanosomatid Crithidia deanei. J Euk Microbiol 1997; 44: 492-6.

[18] Motta MCM, Sole-Cava AM, Soares MJ, et al. Characterization of the trypanosomatids Crithidia desouzai and Herpetomonas anglusteri. Can J Zool 1991; 69: 571-7.

[19] Du Y, Maslov DA, Chang KP. Monophyletic origin of L-division proteobacterial endosymbionts and their coevolution with insect trypanosomatid protozoa Blastocrithidia culicis and Crithidia spp. Proc Natl Acad Sci USA 1994; 91: 8437-41.

[20] Du Y, Chang KP. Phylogenetic heterogeneity of three Crithidia spp. vs. Crithidia fasciculata. Mol Biochem Parasitol 1994; 66: 171-4.
[21] Hollar L, Lukes J, Maslov DA. Monophyly of endosymbiont containing trypanosomatids: phylogeny versus taxonomy. J Eukaryot Microbiol 1998; 45: 293-7.

[22] De Souza MA, Corte-Real S. Postnuclear kinetoplast in choanomastigotes of Crithidia deanei Carvalho, 1973. Proposoal of a new genus. Rev Int Med Trop S Paulo 1991; 33: S8.

[23] Brandão AA, Miranda A, Degrave WM, Sousa MA. The heterogeneity of choanomastigote-shaped trypanosomatids as analyzed by their kDNA minicircle size: taxonomic implications. Parasitol Res 2000; 86: 809-12.

[24] Du Y, McLaughlin G, Chang KP. 16S ribosomal DNA sequence identices of L-proteobacterial endosymbionts in three Crithidia species. J Bacteriol 1994; 176: 3081-4.

[25] Marmur J, Cahoon ME, Shimura Y, Vogel H. DNA type attributable to a bacterial endosymbiote in the protozoon, Crithidia (Strigomonas) oncopelti. Nature 1963; 196: 1228-9.

[26] Gutteridge WE, Macadam RF. An electron microscopic study of the bipolar bodies in Crithidia oncopelti. J Protozool 1971; 18: 637-44.

[27] Chang KP. Ultrastructure of symbiote bacteria in normal and antibiotic treated Blastocrithidia culicis and Crithidia oncopelti. J Protozool 1974; 21: 699-707.

[28] Soares MJ, De Souza W. Freeze-fracture study of the endosymbiont of Blastocrithidia culicis. J Protozool 1988; 35: 370-4.

[29] Motta MCM, Soares MJ, De Souza W. Freeze-fracture study of the endosymbiont-bearing trypanosomatids of the Crithidia genus. Microcs Electron Biol 1991; 15: 131-44.

[30] Motta MCM, Picchi GFA, Palmié-Peixoto IV, et al. The microtubule analog protein, FtsZ, in the endosymbiont of trypanosomatid protozoa. J Eukaryot Microbiol 2004; 51: 394-401.

[31] Palmié-Peixoto I, Rocha MR, Urbina J, et al. Effects of sterolbiosynthesis inhibitors on endosymbiont-bearing trypanosomatids. FEMS Microbiol Lett 2006; 255, 33-42.

[32] López-Lara IM, Geiger O. Novel pathway for phosphatidylcholine biosynthesis in bacteria associated with eukaryotes. J Biotechnol 2001; 91: 211-21.

[33] de Rudder KEE, López-Lara IM, Geiger O. Inactivation of the gene for phospholipids N-methyltransferase in Sinorhizobium melioti: phosphatidylcholine is required for normal growth. Mol Microbiol 2000; 37: 763-72.

[34] Wessel M, Klüsener S, Gödeke J, et al. Virulence of Agrobacterium tumefaciens requires phosphatidylcholine in the bacterial membrane. Mol Microbiol 2006; 62: 906-15.

[35] Azevedo-Martins AC, Frossard ML, De Souza W, Einicker-Lamas M, Motta MCM. Phosphatidylcholine synthesis in Crithidia deanei: the influence of the endosymbiont. FEMS Microbiol Lett 2007; 275: 229-36.

[36] Novak E, Freymuller E, Da Silva S, Da Silveira JF. Protein synthesis in isolated symbionts from the flagellate protozoon Crithidia deanei. J Protozool 1988; 35: 375-8.

[37] De Souza W. Basic cell biology of Trypanosoma cruzi. Curr Pharm Des 2002; 8: 269-85.

[38] Motta MCM, Soares MJ, Attias M, et al. Ultrastructural and biochemical analysis of the relationship of Crithidia deane $i$ with its endosymbiont. Eur J Cell Biol 1997; 72: 370-7.

[39] Faria e Silva PM, Attias M, De Souza W. Biochemical and ultrastructural changes in Herpetomonas roitmani related to the energy metabolism. Biol Cell 2000; 92: 39-47.

[40] Freymüller E, Camargo EP. Ultrastructural differences between species of trypanosomatids with and without endosymbionts. J Protozool 1981; 2: 175-82.

[41] Cavalcanti DP, Thiry M, De Souza W, Motta MCM. The kinetoplast ultrastructural organization of endosymbiont-bearing trypanosomatids as revealed by deep-etching, cytochemical and immunocytochemical analysis. Histochem Cell Biol 2008; 130:1177-85.

[42] Bastin P, Sherwin T, Gull K. Paraflagellar rod is vital for trypanosome motility. Nature 1998; 391: 548.

[43] Bastin P, Pullen TJ, Moreira-Leite FF, Gull K. Inside and outside of the trypanosome flagellum:a multifunctional organelle. Microbes Infect 2000; 2: 1865-74.

[44] Gadelha C, Wickstead B, De Souza W, Gull K, Cunha-e-Silva N. Cryptic paraflagellar rod in endosymbiont-containing kinetoplastid protozoa. Eukaryot Cell 2005; 4: 516-24.

[45] Corrêa-da-Silva MS, Fampa P, Lessa LP, et al. Colonization of Aedes aegypti midgut by the endosymbiont-bearing trypanosomatid Blastocrithidia culicis. Parasitol Res 2006; 99: 384-91. 
[46] Dwyer DM, Chang KP. Surface membrane carbohydrate alterations of a flagellated protozoan mediated by bacterial endosymbionts. Proc Natl Acad Sci USA 1976; 73: 852-6.

[47] Esteves MJG, Andrade AFB, Angluster J, et al. Cell surface carbohydrates in Crithidia deanei: influence of the endosymbiont. Eur J Cell Biol 1982; 28: 244-8.

[48] McLaughlin GL, Cain GD. Characterization of whole-cell and organelle protein synthesis in normal and aposymbiotic strains of Crithidia oncopelti and Blastocrithidia culicis. Comp Biochem Physiol 1985; 82: 479-86.

[49] Faria e Silva PM, Fiorini JE, Soares MJ, et al. Membraneassociated polysaccharides composition, nutritional requirements and cell differentiation in Herptomonas roitmani: influence of the endosymbiont. J Eukaryot Microbiol 1994; 41: 55-9.

[50] d'Ávila-Levy CM, Silva BA, Hayashi EA, et al. Influence of the endosymbiont of Blastocrithidia culicis and Crithidia deanei on the glycoconjugate expression and on Aedes aegypti interaction. FEMS Microbiol Lett 2005; 252: 279-86.

[51] Oda LM, Alviano CS, Costa e Silva Filho F, et al. Surface anionic group in symbiot-bearing and symbiont-free strains of Crithidia deanei. J Protozool 1984; 31: 131-4.

[52] Wallace FG. The trypanosomatids parasites of insects and arachnids. Exp Parasitol 1966; 18: 124-93.

[53] Podlipaev SA. Insect trypanosomatids: the need to know more. Mem Inst Oswaldo Cruz 2000; 95: 517-22.

[54] Sajid M, McKerrow JH. Cysteine proteases of parasitic organisms. Mol Biochem Parasitol 2002; 120: 1-21. Erratum in: Mol Biochem Parasitol 2002; 121: 159.

[55] d'Avila-Levy CM, Santos LO, Marinho FA, et al. Crithidia deanei: influence of parasite gp63 homologue on the interaction of endosymbiont-harboring and aposymbiotic strains with Aedes aegypti midgut. Exp Parasitol 2008; 118: 345-53.

[56] Gazzinelli RT, Romanha AJ, Fontes G, et al. Distribution of carbohydrates recognized by the lectins Euonymus europaeus and concanavalin A in monoxenic and heteroxenic trypanosomatids. J Protozool 1991; 38: 320-5.

[57] De Souza W. Structural organization of the cell surface of pathogenic protozoa. Micron 1995; 26: 405-30.

[58] Sacks DL, Kamhawi S. Molecular aspects of parasite-vector interactions in leishmaniasis. Annu Rev Microbiol 2001; 55: 453-83.

[59] McGhee RB, Cosgrove WB. Biology and physiology of the lower Trypanosomatidae. Microbiol Rev 1980; 44: 140-73.

[60] Jansen AM, Carreira JC, Deane MP. Infection of a mammal by monogenetic insect trypanosomatids (Kinetoplastida, Trypanosomatidae). Mem Inst Oswaldo Cruz 1988; 83: 271-2.

[61] Rozental S, de Carvalho TU, de Souza W. Influence of the endosymbiont on the interaction of Crithidia deanei with macrophages. Microsc Electron Biol Cell 1987; 11: 167-77.

[62] Matteoli FP, d'Avila-Levy CM, Santos LO, et al. Roles of the endosymbiont and leishmanolysin-like molecules expressed by Crithidia deanei in the interaction with mammalian fibroblasts. Exp Parasitol 2009; 121: 246-53.

[63] Santos DO, Bourguignon SC, Castro HC, et al. Infection of mouse dermal fibroblasts by the monoxenous trypanosomatid protozoa Crithidia deanei and Herpetomonas roitmani. J Eukaryot Microbiol 2004; 51: 570-4.

[64] Hervás Rodríguez J, Mozos E, Méndez A, et al. Leishmania infection of canine skin fibroblasts in vivo. Vet Pathol 1996; 33: 469-73.

[65] Pacheco RS, Marzochi MCA, Pires MQ, et al. Parasite genotypically related to a monoxenous trypanosomatids of dog's flea causing opportunistic infection in an HIV positive patient. Mem Inst Oswaldo Cruz 1998; 93: 531-7.
[66] Morio F, Reynes J, Dollet M, et al. Isolation of a protozoan parasite genetically related to the insect trypanosomatid Herpetomonas samuelpessoai from a human immunodeficiency virus-positive patient. J Clin Microbiol 2008; 46: 3845-7.

[67] Barreto-de-Souza V, Medeiros TX, Motta MCM, Bou-Habib DC, Saraiva EM. HIV-1 infection and HIV-1 Tat protein permit the survival and replication of a non-pathogenic trypanosomatid in macrophages through TGF-betal production. Microbes Infect 2008; 10: 642-9.

[68] Dedet JP, Pratlong F. Leishmania, Trypanosoma and monoxenous trypanosomatids as emerging opportunistic agents. J Eukaryot Microbiol 2000; 47: 37-9.

[69] Lwoff M. Aneurin as a growth factor for the trypanosomatids £agellate Strigomonas oncopelti. C R Soc Biol Paris 1937; 126: 771-3.

[70] Newton BA. Nutritional requirements and biosynthetic capabilities of the parasitic £agellate Strigomonas oncopelti. J Gen Microbiol 1957; 17: 708-17.

[71] Chang KP, Trager W. Nutritional significance of symbiotic bacteria in two species of hemoflagellates. Science 1974; 183: 531-2.

[72] d'Avila-Levy CM, Melo AC, Vermelho AB, Branquinha MH. Differential expression of proteolytic enzymes in endosymbiontharboring Crithidia species. FEMS Microbiol Lett 2001; 202: 73-7.

[73] Chang KP, Chang CS, Sassa S. Heme biosynthesis in bacteriumprotozoon symbioses: enzymic defects in host hemo£agellates and complemental role of their intracellular symbiotes. Proc Natl Acad Sci USA 1975; 72: 2979-83.

[74] Salzman TA, Del C Battle AM, Angluster J, De Souza W. Heme synthesis in Crithidia deanei: influence of the endosymbiont. Int $\mathbf{J}$ Biochem 1985; 17: 1343-7.

[75] Gill JW, Vogel HJ. A bacterial endosymbiont on Crithidia (Strigomonas) oncopelti: biochemical and morphological aspects. J Protozool 1963; 10: 148-52.

[76] Camargo EP, Freymüller E. Endosymbiont as supplier of ornithine carbamoyl transferase in a trypanosomatid. Nature 1977; 270: 52-3.

[77] Figueiredo EN, Yoshida N, Roitman C, Camargo EP. Enzymes of the ornithine-arginine metabolism of trypanosomatids of the genus Crithidia. J Protozool 1978; 25: 546-9.

[78] Galinari S, Camargo EP. Trypanosomatid protozoa: survey of acetylornithinase and ornithine acetyltransferase. Exp Parasitol 1978; 46: 277-82.

[79] Kidder GW, Davis JS, Cousens K. Citrulline utilization in Crithidia. Biochem Biphys Res Commun 1966; 24: 365- 9.

[80] Lipschik G, Devery J, Haddad J, et al. Polyamine and $\mathrm{Mg}^{2+}$ content of trypanosomatids. J Protozool 1976; 23: 30.

[81] Yoshida N, Jankevicius J, Roitman I, Camargo EP. Enzymes of the ornithine -artginine metabolism of trypanosomatids of the genus Herpetomonas. J Protozool 1978; 25: 550-5.

[82] Sylvester D, Krassner SM. Proline metabolism in Trypanosoma cruzi epimastigotes. Comp Biochem Physiol B 1976; 55: 443-7.

[83] Bursell JD, Kirk J, Hall ST, Gero AM, Kirk K. Volume-regulatory amino acid release from the protozoan parasite Crithidia luciliae. J Membr Biol 1996; 154: 131-41.

[84] Rojas GRL, Frossard ML, Motta MMC, Silber AM. L-Proline uptake in Crithidia deanei is influenced by its endosymbiont bacterium. FEMS Microbiol Lett 2008; 283: 15-22.

[85] Heby O, Persson L. Molecular genetics of polyamine synthesis in eukaryotic cells. Trends Biochem Sci 1990; 15: 153-8.

[86] Pegg AE, Shantz LM, Coleman CS. Ornithine decarboxylase as a target for chemoprevention. J Cell Biochem 1995; 58: 132-8.

[87] Frossard ML, Seabra SH, DaMatta RA, et al. An endosymbiont positively modulates ornithine decarboxylase in host trypanosomatids. Biochem Biophys Res Commun 2006; 343: 443-9.

Received: October 12, 2009

(C) Maria Cristina M. Motta; Licensee Bentham Open.

This is an open access article licensed under the terms of the Creative Commons Attribution Non-Commercial License (http://creativecommons.org/licenses/by-nc/3.0/) which permits unrestricted, non-commercial use, distribution and reproduction in any medium, provided the work is properly cited. 